\title{
Coccinonectria pachysandricola, Causal Agent of a New Foliar Blight Disease of Sarcococca hookeriana
}

\author{
Catalina Salgado-Salazar, ${ }^{1,2}$ Nina Shiskoff, ${ }^{3}$ Nicholas LeBlanc, ${ }^{1,2}$ Adnan A. Ismaiel, ${ }^{1}$ Maxton Collins, ${ }^{4}$ Marc A. Cubeta, ${ }^{4}$ \\ and Jo Anne Crouch, ${ }^{1, \dagger}$ \\ ${ }^{1}$ Mycology and Nematology Genetic Diversity and Biology Laboratory, U.S. Department of Agriculture, Agricultural Research Service, \\ Beltsville, MD 20705; ${ }^{2}$ Oak Ridge Institute for Science and Education, Agricultural Research Service Research Participation Program, \\ Oak Ridge, TN 37830; ${ }^{3}$ Foreign Disease/Weed Science Research Unit, U.S. Department of Agriculture, Agricultural Research \\ Service, Frederick, MD 21702; and ${ }^{4}$ Center for Integrated Fungal Research, Department of Entomology and Plant Pathology, \\ North Carolina State University, Raleigh, NC 27695
}

\begin{abstract}
Woody plants of the Buxaceae, including species of Buxus, Pachysandra, and Sarcococca, are widely grown evergreen shrubs and groundcovers. Severe leaf spot symptoms were observed on S. hookeriana at the U.S. National Arboretum in Washington, DC, in 2016. Affected plants were growing adjacent to $P$. terminalis exhibiting Volutella blight symptoms. Fungi isolated from both hosts were identical based on morphology and multilocus phylogenetic analysis and were identified as Coccinonectria pachysandricola (Nectriaceae, Hypocreales), causal agent of Volutella blight of Pachysandra species. Pathogenicity tests established that Co. pachysandricola isolated from both hosts caused disease symptoms on $P$. terminalis

and S. hookeriana, but not on B. sempervirens. Artificial inoculations with Pseudonectria foliicola, causal agent of Volutella blight of $B$. sempervirens, did not result in disease on P. terminalis or $S$. hookeriana. Wounding enhanced infection by $C o$. pachysandricola and $P$ s. foliicola on all hosts tested but was not required for disease development. Genome assemblies were generated for the Buxaceae pathogens that cause Volutella diseases: Co. pachysandricola, Ps. buxi, and Ps. foliicola; these ranged in size from 25.7 to $28.5 \mathrm{Mb}$. To our knowledge, this foliar blight of $S$. hookeriana represents a new disease for this host and is capable of causing considerable damage to infected plants.
\end{abstract}

Plants in the family Buxaceae such as species of Buxus (boxwood), Pachysandra (pachysandra), and Sarcococca (sarcococca, or sweet box) are high-value broadleaf ornamental evergreen shrubs and groundcovers. The most popular members of the family, species of Buxus and Pachysandra, are widely planted in landscapes worldwide. Plants in the genus Sarcococca are less well known, but they are valued in the horticultural trade and in the landscape for their dark, glossy evergreen foliage, dense leaf structure, fragrant white to light-pink flowers, and their ability to thrive in shady areas (Denaeghel et al. 2017; Sealy 1986). Boxwood and the widely planted Japanese pachysandra ( $P$. terminalis) are subject to losses attributable to several diseases and pests. The most notable disease problems, affecting one or both of these important nursery crops, are boxwood blight (caused by Calonectria henricotiae and C. pseudonaviculata), Volutella blights (caused by Coccinonectria pachysandricola, Pseudonectria buxi, and Ps. foliicola), Macrophomina blight (caused by Dothiorella candollei), boxwood rust (caused by Puccinia buxi),

${ }^{\dagger}$ Corresponding author: J. A. Crouch; joanne.crouch@ars.usda.gov

Funding: This work was supported by U.S. Department of Agriculture Agricultural Research Service (USDA ARS) projects 8042-22000-298-00-D and 8044-22000-045-00-D, the USDA ARS Floriculture and Nursery Research Initiative, and the appointments of C. Salgado-Salazar and N. LeBlanc to the ARS Research Participation Program administered by the Oak Ridge Institute for Science and Education (ORISE) through an interagency agreement between the U.S. Department of Energy and the USDA. ORISE is managed by Oak Ridge Associated Universities under U.S. Department of Energy contract number DE-AC05-06OR23100.

*The $\boldsymbol{e}$-Xtra logo stands for "electronic extra" and indicates that one supplementary figure is published online.

The author(s) declare no conflict of interest.

Accepted for publication 28 November 2018.

(C) 2019 The American Phytopathological Society and Phytophthora root rot (caused by Phytophthora nicotianae) (Batdorf 2005; Farr and Rossman 2018; LeBlanc et al. 2018). In contrast, plants in the genus Sarcococca are considered virtually pest and pathogen free. Although 24 fungi and oomycetes are documented in association with species of Sarcococca, for all but one of these organisms, reports are limited to observations of the fungus or oomycete without reference to host disease symptoms or pathogenicity (Farr and Rossman 2018; Kong et al. 2017a; Malapi-Wight et al. 2016). The only disease described from sarcococca is a foliar and twig blight caused by $C$. pseudonaviculata, reported from the midAtlantic region of the United States in two residential locations where affected sarcococca plants were grown adjacent to $B$. sempervirens 'Suffruticosa' exhibiting boxwood blight disease (Kong et al. 2017a; Malapi-Wight et al. 2016).

In September 2016, several established S. hookeriana plants in the National Boxwood Collection at the U.S. National Arboretum (USNA) in Washington, DC, exhibited blighted leaves with dead or dying stems (Fig. 1). Symptoms did not resemble those caused by C. pseudonaviculata (Kong et al. 2017a; Malapi-Wight et al. 2016). The diseased sarcococca were growing immediately adjacent to a stand of severely blighted $P$. terminalis exhibiting disease symptoms consistent with Volutella blight, a fungal disease caused by $C o$. pachysandricola (Lombard et al. 2015). The concentric banding pattern present on the sarcococca lesions resembled the leaf lesions on adjacent pachysandra, but it was unknown whether the two hosts were infected by the same pathogen. In this study, we determined the identity of the fungus responsible for this new blight disease of sarcococca and we conducted experiments to determine whether the fungus was also capable of causing disease on boxwood and pachysandra. In addition, next-generation sequence technologies were used to generate genome resources for the three fungal species known to cause Volutella blight of hosts in the Buxaceae.

\section{Materials and Methods}

Disease sampling and fungal isolates. Diseased $P$. terminalis and $S$. hookeriana leaves were collected from the National Boxwood Collection. Samples were collected from USNA bed BOX-S, where 
the main sign for the National Boxwood Collection is located $\left(38^{\circ} 54^{\prime} 42^{\prime \prime} \mathrm{N}, 76^{\circ} 58^{\prime} 33^{\prime \prime} \mathrm{W}\right)$. Affected plants were growing in full sun throughout the day. Plants were identified to the species level based on morphological features with the assistance of USNA curators, as the pachysandra and sarcococca in the bed were not accessioned in the collection and their origins were not recorded. The age of the plants was unknown; however, USNA curators indicated that the plants have been in this location since at least 2005
A summary of the fungal isolates included in this study is provided in Table 1. To identify the pathogens affecting the diseased plants, leaves from two symptomatic $S$. hookeriana and three symptomatic $P$. terminalis were used to establish fungal cultures. Small samples (approximately $5 \mathrm{~mm} \times 5 \mathrm{~mm}$ ) at the margins of diseased and healthy tissues were surface sterilized in $70 \%$ ethanol for $30 \mathrm{~s}$, then in $0.5 \%$ sodium hypochlorite for $1 \mathrm{~min}$, followed by two washes in sterilized distilled water for $30 \mathrm{~s}$. The surface-sterilized leaf fragments were dried using sterile paper towels and placed on potato dextrose agar
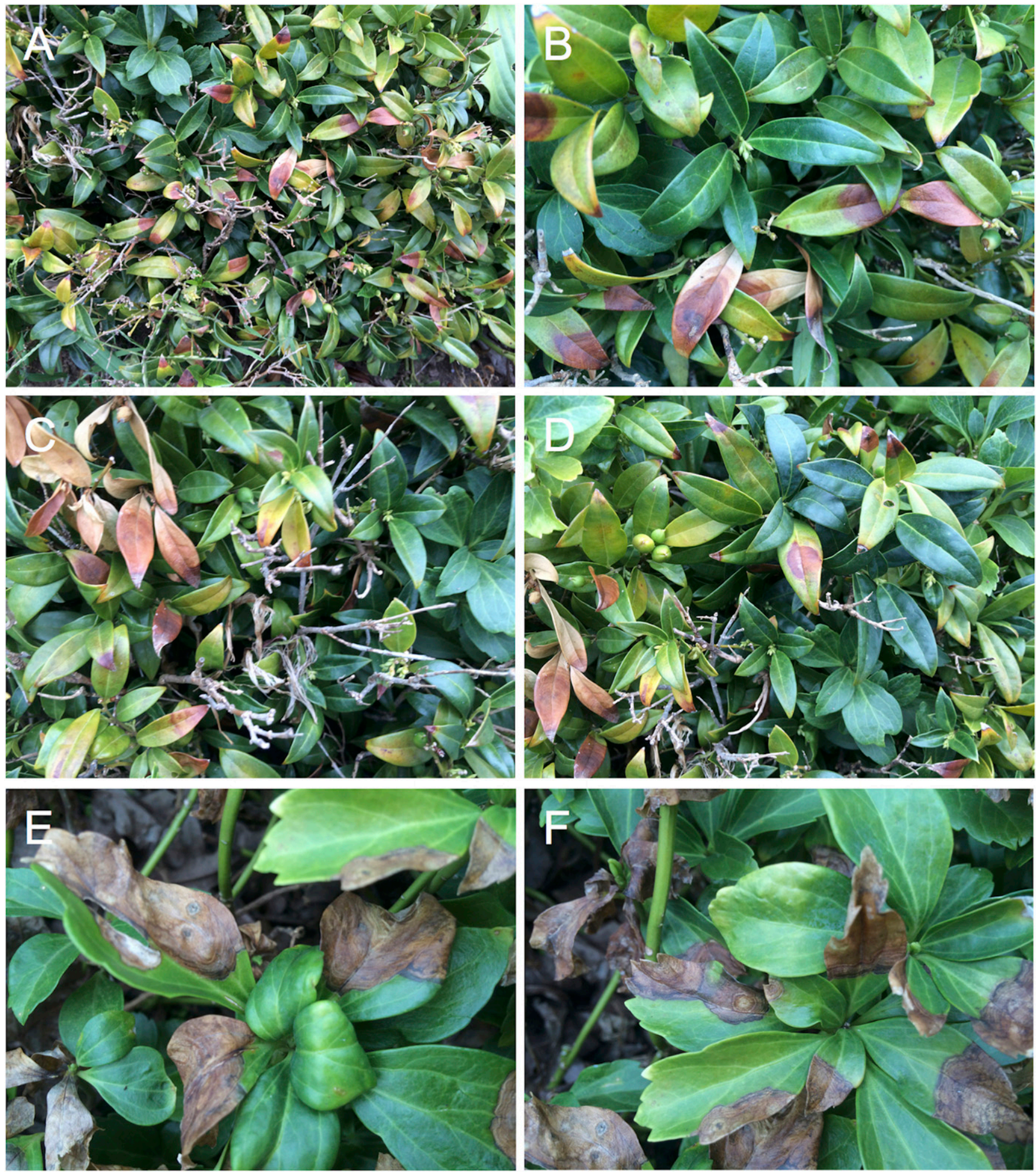

Fig. 1. Disease symptoms caused by Coccinonectria pachysandricola on Sarcococca hookeriana var. humilis and Pachysandra terminalis plants grown in the U.S. National Arboretum in Washington D.C. A, B, C, and D, S. hookeriana var. humilis. E and F, P. terminalis. 
(PDA; Fisher Scientific, Pittsburgh, PA) media amended with streptomycin and neomycin ( $0.3 \mathrm{~g}$ per liter). Plates were incubated for 5 days at $25^{\circ} \mathrm{C}$. Hyphal tips of the mycelia of one representative fungal colony per plant growing out of the surface-sterilized tissues were replated on PDA and used for DNA extraction and morphological studies.

Additional fungal isolates for comparative purposes were either newly collected for this study or were obtained from the Westerdijk Fungal Biology Institute in Utrecht, The Netherlands (CBS). Isolates include reference strains of Co. pachysandricola and of the closely related species Ps. buxi, Ps. foliicola, Volutella ciliata, $V$. consors, and outgroup taxa (Cosmospora coccinea and Nectria pseudotrichia).
Morphological characterization. Morphological structures were assessed from fungal colonies growing on PDA and on synthetic nutrient-deficient agar (Nirenberg 1976). Petri plates were incubated at $25^{\circ} \mathrm{C}$ with a 12 -h photoperiod for 5 to 7 days to observe sporulation. Growth rates and colony characteristics were obtained from PDA plates inoculated with mycelial plugs ( $4 \mathrm{~mm}$ in diameter) and incubated at $25^{\circ} \mathrm{C}$. Color terminology was based on Rayner (1970). Morphological characteristics were determined by mounting fungal structures in 3\% $\mathrm{KOH}$. Microscopic observations were performed on a Zeiss Axio Imager M2 microscope (Carl Zeiss Microscopy, Thornwood, NY). Images were acquired using an Axiocam 503 color digital camera with differential interference contrast illumination and processed using ZEN 2 Pro software (Carl Zeiss

Table 1. Details of fungal isolates used in the phylogenetic analyses

\begin{tabular}{|c|c|c|c|c|c|c|c|c|c|c|}
\hline Species name & Isolate number & Host & Location & acl1 & CaM & his3 & ITS & RPB1 & RPB2 & Reference \\
\hline $\begin{array}{l}\text { Coccinonectria } \\
\text { pachysandricola }\end{array}$ & AR 2707 & $\begin{array}{c}\text { Pachysandra } \\
\text { terminalis }\end{array}$ & MD, U.S.A. & MH936719a & MH936823 & MH936787 & MH892573 ${ }^{a}$ & MH936753 ${ }^{a}$ & MH936680 & This study \\
\hline Co. pachysandricola & $\begin{array}{l}\text { AR } 4592, \text { CBS } \\
128674\end{array}$ & P. terminalis & MD, U.S.A. & KM230981 & MH936828 ${ }^{\mathrm{a}}$ & MH936792 ${ }^{\mathrm{a}}$ & JF832658 & JF832791 & $\begin{array}{l}\text { KM232351, } \\
\text { MH936715 }^{\mathrm{a}}\end{array}$ & $\begin{array}{l}\text { Lombard } \\
\text { et al. } 2015\end{array}$ \\
\hline Co. pachysandricola & CBS 476.92 & P. terminalis & $\begin{array}{l}\text { The } \\
\text { Netherlands }\end{array}$ & KM230980 & MH936838 & KM231498 & KM231775 & KM232191 & MH936693 & $\begin{array}{l}\text { Lombard } \\
\text { et al. } 2015\end{array}$ \\
\hline Co. pachysandricola & CBS 501.63 & P. terminalis & Germany & KM230979 & MH936840 ${ }^{\mathrm{a}}$ & KM231497 & KM231774 & KM232190 & KM232350 & $\begin{array}{l}\text { Lombard } \\
\text { et al. } 2015\end{array}$ \\
\hline Co. pachysandricola & $\begin{array}{l}\text { JAC 16-16, }{ }^{\mathrm{b}} \text { CBS } \\
144731\end{array}$ & $\begin{array}{l}\text { Sarcoccocca } \\
\text { hookeriana } \\
\text { var. humilis }\end{array}$ & DC, U.S.A. & MH936737 ${ }^{\mathrm{a}}$ & MH936845 ${ }^{\mathrm{a}}$ & MH936807 & MH892592 ${ }^{\mathrm{a}}$ & MH936771 ${ }^{\mathrm{a}}$ & MH936699 & This study \\
\hline Co. pachysandricola & JAC $16-17$ & $\begin{array}{c}\text { S. hookeriana } \\
\text { var. humilis }\end{array}$ & DC, U.S.A. & MH936738 & MH936772a & MH936808 & MH892593 & MH936772a & MH936700 & This study \\
\hline Co. pachysandricola & JAC $16-18$ & P. terminalis & DC, U.S.A. & MH936739 ${ }^{\mathrm{a}}$ & MH936847 ${ }^{\mathrm{a}}$ & MH936809 ${ }^{\mathrm{a}}$ & MH892594 ${ }^{\mathrm{a}}$ & MH936773 ${ }^{\mathrm{a}}$ & MH936701 ${ }^{\mathrm{a}}$ & This study \\
\hline Co. pachysandricola & JAC $16-19$ & P. terminalis & DC, U.S.A. & MH936740 ${ }^{\mathrm{a}}$ & MH936848 ${ }^{\mathrm{a}}$ & MH936810 & MH892595 & MH936774 ${ }^{\mathrm{a}}$ & MH936702 & This study \\
\hline Co. pachysandricola & JAC $16-20$ & P. terminalis & DC, U.S.A. & MH936741 ${ }^{\mathrm{a}}$ & MH936849 ${ }^{\mathrm{a}}$ & MH936811 ${ }^{\mathrm{a}}$ & MH892596 ${ }^{\mathrm{a}}$ & MH936775 & MH936703 ${ }^{\mathrm{a}}$ & This study \\
\hline Cosmopara coccinea & AR 2741 & $\begin{array}{l}\text { Inonotus } \\
\quad \text { nodulosushymenium }\end{array}$ & Germany & MH936724 ${ }^{\mathrm{a}}$ & MH936828 ${ }^{a}$ & MH936794 & MH892578 & MH936758 & MH936685 & This study \\
\hline Cosmopara coccinea & CBS 341.70 & I. nodulosushymenium & Germany & HQ897913 & KM231389 & KM231550 & HQ897827 & KM232242 & HQ897777 & $\begin{array}{l}\text { Lombard } \\
\text { et al. } 2015\end{array}$ \\
\hline Nectria pseudotrichia & CBS 451.85 & Pinus teumumanii & Honduras & MH936731 ${ }^{\mathrm{a}}$ & MH936837 ${ }^{\mathrm{a}}$ & MH936801 ${ }^{\mathrm{a}}$ & MH892586 & MH936766 ${ }^{\mathrm{a}}$ & MH936692 ${ }^{\mathrm{a}}$ & $\begin{array}{l}\text { Hirooka et al. } \\
2012\end{array}$ \\
\hline N. pseudotrichia & CBS 531.84 & Unknown & Japan & MH936733 ${ }^{a}$ & MH936841 ${ }^{\mathrm{a}}$ & MH936803 & MH892588 & - & MH936695 & $\begin{array}{l}\text { Hirooka et al. } \\
2012\end{array}$ \\
\hline $\begin{array}{l}\text { Pseudonectria } \\
\text { buxi }\end{array}$ & AR 2708 & Buxus sp. & MD, U.S.A. & MH936720 a & MH936824 ${ }^{\mathrm{a}}$ & MH936788 & MH892574 ${ }^{\mathrm{a}}$ & MH936754 ${ }^{\mathrm{a}}$ & MH936681 ${ }^{\mathrm{a}}$ & This study \\
\hline Ps. buxi & $\begin{array}{l}\text { AR 2714, }{ }^{\text {b }} \text { CBS } \\
144729\end{array}$ & B. sempervirens & Spain & MH936722 ${ }^{\mathrm{a}}$ & MH936826a & MH936790 & MH892576 & MH936756 ${ }^{\mathrm{a}}$ & MH936683 & This study \\
\hline Ps. buxi & CBS 234.75 & B. sempervirens & France & MH936728 ${ }^{\mathrm{a}}$ & MH936833 ${ }^{\mathrm{a}}$ & MH936797 & MH892582 ${ }^{\mathrm{a}}$ & MH936762 ${ }^{\mathrm{a}}$ & MH936689 & $\begin{array}{l}\text { Lombard } \\
\text { et al. } 2015\end{array}$ \\
\hline Ps. buxi & CBS 252.69 & B. sempervirens & $\begin{array}{l}\text { The } \\
\text { Netherlands }\end{array}$ & MH936729 ${ }^{\mathrm{a}}$ & MH936763 ${ }^{\mathrm{a}}$ & MH936798 & MH892583 & MH936763 ${ }^{\mathrm{a}}$ & MH936690 & $\begin{array}{l}\text { Lombard } \\
\text { et al. } 2015\end{array}$ \\
\hline Ps. buxi & CBS 647.82 & B. sempervirens & Belgium & MH936734 ${ }^{\mathrm{a}}$ & MH936842 & MH936804 ${ }^{\mathrm{a}}$ & MH892589 & MH936768 ${ }^{\mathrm{a}}$ & MH936696 ${ }^{\mathrm{a}}$ & $\begin{array}{l}\text { Lombard } \\
\text { et al. } 2015\end{array}$ \\
\hline Ps. buxi & JAC $17-18$ & Buxus sp. & MD, U.S.A. & MH936744 ${ }^{\mathrm{a}}$ & MH936852 ${ }^{\mathrm{a}}$ & MH936814 ${ }^{\mathrm{a}}$ & MH892599 ${ }^{a}$ & MH936778 ${ }^{\mathrm{a}}$ & MH936706 ${ }^{\mathrm{a}}$ & This study \\
\hline Ps. buxi & AR 2715 & B. sempervirens & Spain & MH936723 ${ }^{a}$ & MH936827 & MH936791 ${ }^{\mathrm{a}}$ & MH892577 & MH936757 ${ }^{a}$ & MH936684 ${ }^{\mathrm{a}}$ & This study \\
\hline Ps. foliicola & AR 2711 & B. sempervirens & MD, U.S.A. & MH936721 ${ }^{\mathrm{a}}$ & MH936825 & MH936789 & MH892575 & MH936755 ${ }^{\mathrm{a}}$ & MH936682 ${ }^{\mathrm{a}}$ & This study \\
\hline Ps. foliicola & $\begin{array}{l}\text { CBS } 123190,{ }^{\mathrm{c}} \text { AR } \\
2709\end{array}$ & B. sempervirens & New Zealand & MH936726 ${ }^{\mathrm{a}}$ & MH936831 ${ }^{\mathrm{a}}$ & MH936795 & MH892580 & MH936760 ${ }^{\mathrm{a}}$ & MH936687 & $\begin{array}{l}\text { Lombard } \\
\text { et al. } 2015\end{array}$ \\
\hline Ps. foliicola & JAC $12-83$ & B. sempervirens & MA, U.S.A. & MH936735 ${ }^{\mathrm{a}}$ & MH936843 ${ }^{\mathrm{a}}$ & MH936805 & MH892590 & MH936769 ${ }^{a}$ & MH936697 & This study \\
\hline Ps. foliicola & JAC $16-15$ & Buxus sp. & IL, U.S.A. & MH936736 ${ }^{\mathrm{a}}$ & MH936844 ${ }^{\mathrm{a}}$ & MH936806 ${ }^{\mathrm{a}}$ & MH892591 ${ }^{a}$ & MH936770 & MH936698 ${ }^{a}$ & This study \\
\hline Ps. foliicola & JAC $17-03$ & Buxus sp. & IL, U.S.A. & MH936742 & MH936850 & MH936812 & MH892597 & MH936776 ${ }^{\mathrm{a}}$ & MH936704 ${ }^{\mathrm{a}}$ & This study \\
\hline Ps. foliicola & JAC $17-04$ & Buxus sp. & WA, U.S.A. & MH936743 ${ }^{\mathrm{a}}$ & MH936851 ${ }^{\mathrm{a}}$ & MH936813 & MH892598 & MH936777 & MH936705 ${ }^{\mathrm{a}}$ & This study \\
\hline Ps. foliicola & JAC $17-19$ & Buxus sp. & MD, U.S.A. & MH936745 ${ }^{\mathrm{a}}$ & MH936853 ${ }^{a}$ & MH936815 & MH892600 & MH936779 ${ }^{a}$ & MH936707 ${ }^{a}$ & This study \\
\hline Ps. foliicola & JAC $17-40$ & Buxus sp. & NC, U.S.A. & MH936746 & MH936854 ${ }^{\mathrm{a}}$ & MH936816 & MH892601 ${ }^{a}$ & MH936780 & MH936708 ${ }^{a}$ & This study \\
\hline Ps. foliicola & JAC $17-41$ & Buxus sp. & NC, U.S.A. & MH936747 ${ }^{\mathrm{a}}$ & MH936855 ${ }^{\mathrm{a}}$ & MH936817 & MH892602 ${ }^{\mathrm{a}}$ & MH936781 ${ }^{a}$ & MH936709 & This study \\
\hline Ps. foliicola & JAC $17-42$ & Buxus sp. & NC, U.S.A. & MH936748 & MH936856 & MH936818 & MH892603 & MH936782 ${ }^{\mathrm{a}}$ & MH936710 & This study \\
\hline Ps. foliicola & $\begin{array}{l}\text { JAC } 18-02,{ }^{b} \text { CBS } \\
144753\end{array}$ & S. hookeriana & NC, U.S.A. & MH936749 ${ }^{\mathrm{a}}$ & MH936857 ${ }^{\mathrm{a}}$ & MH936819 & MH892604 ${ }^{\mathrm{a}}$ & MH936783 ${ }^{\mathrm{a}}$ & MH936711 ${ }^{\mathrm{a}}$ & This study \\
\hline Ps. foliicola & JAC 18-04 & S. confusa & NC, U.S.A. & MH936750 ${ }^{\mathrm{a}}$ & - & MH936820 & MH892605 ${ }^{\mathrm{a}}$ & MH936784 ${ }^{\mathrm{a}}$ & MH936712 ${ }^{\mathrm{a}}$ & This study \\
\hline Ps. foliicola & JAC $18-07$ & Sarcococca sp. & NC, U.S.A. & MH936751 ${ }^{\mathrm{a}}$ & MH936858 ${ }^{a}$ & MH936821 ${ }^{\mathrm{a}}$ & MH892606 & MH936785 a & MH936713 ${ }^{a}$ & This study \\
\hline Ps. foliicola & N1 & B. sempervirens & MD, U.S.A. & MH936752 ${ }^{\mathrm{a}}$ & - & MH936822 ${ }^{\mathrm{a}}$ & MH892607 ${ }^{\mathrm{a}}$ & MH936786 ${ }^{\mathrm{a}}$ & MH936714 ${ }^{\mathrm{a}}$ & This study \\
\hline Volutella ciliata & CBS 100447 & Lyophyllum decastes & $\begin{array}{l}\text { The } \\
\text { Netherlands }\end{array}$ & MH936725 & MH936830 ${ }^{\mathrm{a}}$ & MH936793 ${ }^{\mathrm{a}}$ & MH892579a & MH936759 ${ }^{\mathrm{a}}$ & MH936686 ${ }^{\mathrm{a}}$ & $\begin{array}{l}\text { Gräfenhan } \\
\text { et al. } 2011\end{array}$ \\
\hline$V$. ciliata & CBS 426.52 & Yucca gloriosa & Italy & MH936730 ${ }^{\mathrm{a}}$ & MH936836 ${ }^{\mathrm{a}}$ & MH936800 & MH892585 ${ }^{\mathrm{a}}$ & MH936765 ${ }^{\mathrm{a}}$ & MH936691 ${ }^{\mathrm{a}}$ & $\begin{array}{l}\text { Gräfenhan } \\
\text { et al. } 2011\end{array}$ \\
\hline V. ciliata & CBS 483.61 & Peat soil & Ontario & MH936732 ${ }^{\mathrm{a}}$ & MH936839 & MH936802 ${ }^{\mathrm{a}}$ & MH892587 ${ }^{\mathrm{a}}$ & MH936767 ${ }^{\mathrm{a}}$ & MH936694 ${ }^{\mathrm{a}}$ & $\begin{array}{l}\text { Lombard } \\
\text { et al. } 2015\end{array}$ \\
\hline V. consors & CBS 189.73 & Dianthus caryophyllus & Turkey & MH936727 & MH936832a & МH936796 & MH892580 & MH936761 ${ }^{\mathrm{a}}$ & MH936688 & $\begin{array}{l}\text { Gräfenhan } \\
\text { et al. } 2011\end{array}$ \\
\hline V. consors & CBS 328.77 & Magnolia fraseri & NC, U.S.A. & HQ897854 & MH936835 ${ }^{\mathrm{a}}$ & MH936799 & MH892584 ${ }^{\mathrm{a}}$ & MH936764 ${ }^{\mathrm{a}}$ & MH936716 ${ }^{\mathrm{a}}$ & $\begin{array}{l}\text { Gräfenhan } \\
\text { et al. } 2011\end{array}$ \\
\hline
\end{tabular}

\footnotetext{
a These GenBank accession numbers were newly generated in this study. acl1 = ATP citrate lyase, $\mathrm{CaM}=$ calmodulin, his $3=$ histone 3 , ITS $=$ internal transcribed spacer, and RPB = largest subunit of the RNA polymerase.

${ }^{b}$ Strains used for whole genome sequencing and de novo assembly.

${ }^{\mathrm{c}}$ Ex-type culture.
} 
Microscopy). Size values are reported as ranges (maximum and minimum) followed by mean values.

DNA extraction, polymerase chain reaction amplification, and sequencing. Fungi genotyped through amplicon sequencing were grown on PDA at $25^{\circ} \mathrm{C}$ for 5 days under a 12-h white light photoperiod. Hyphal tissue was harvested from the surface of actively growing colonies, homogenized in 2-ml microcentrifuge tubes using 0.5-mm sterile glass beads (Cell Disruption Media; Scientific Industries Inc., Bohemia, NY) in a FastPrep 24 instrument (MP Biomedicals, Santa Ana, CA) for two cycles of $20 \mathrm{~s}$ in the presence of $600 \mu \mathrm{l}$ of lysis buffer AP1 (QIAGEN Inc., Gaithersburg, MD) and used for DNA extractions using the DNeasy Plant Mini Kit (QIAGEN Inc.). Polymerase chain reaction (PCR) amplicons were generated for six standard molecular markers using the following published primer pairs: the large subunit of the ATP citrate lyase (acl1; primers acl1230up/acl1-1220low; Nowrousian et al. 2000), calmodulin (primers CAL-228F/CAL-737R; Carbone and Kohn 1999), histone 3 (primers CYLH3F/CYLH3R; Crous et al. 2004), rDNA internal transcribed spacer (ITS; primers ITS4/ITS5; White et al. 1990), the largest subunit of the RNA polymerase I (rpb1; primers RPB1a/RPB1C; Castlebury et al. 2004), and the second largest subunit of the RNA polymerase II (rpb2; primers $5 \mathrm{~F} 2 / 7 \mathrm{cR} / 7 \mathrm{cF} / 11 \mathrm{aR}$ O'Donnell et al. 2007). PCR reactions were performed in $20 \mu \mathrm{l}$ volumes containing $10 \mu \mathrm{l}$ of MangoMix (Bioline, Taunton, MA), $0.5 \mu \mathrm{l}$ of each primer $(10 \mu \mathrm{M}), 0.5 \mu \mathrm{l}$ of $25 \mathrm{mM} \mathrm{MgCl}, 7 \mu \mathrm{l}$ of PCR-grade water, and $1.5 \mu \mathrm{l}$ of template DNA $(15 \mathrm{ng} / \mu \mathrm{l})$. Thermal cycling was performed in a PTC 200 Peltier Thermal Cycler (Marshall Scientific, Hampton, $\mathrm{NH}$ ) using the following cycle: $5 \mathrm{~min}$ of denaturation at $95^{\circ} \mathrm{C}$, followed by 30 cycles of $30 \mathrm{~s}$ at $95^{\circ} \mathrm{C}, 30 \mathrm{~s}$ at $55^{\circ} \mathrm{C}$, and $1 \mathrm{~min}$ at $72^{\circ} \mathrm{C}$, followed by a final extension for $10 \mathrm{~min}$ at $72^{\circ} \mathrm{C}$. After treatment with illustra ExoProStar (GE Healthcare Life Sciences, Piscataway, NJ), amplicons were bidirectionally sequenced using ABI BigDye 3.1 Terminator Cycle sequencing chemistry on an ABI 3730x Genetic Analyzer (Life Technologies, Grand Island, NY). Sequences were visually inspected and assembled using CLC Main Workbench v6.9.1 (QIAGEN Inc.).

Phylogenetic analyses. DNA sequence alignments were generated using the online version of MAFFT v7 (http://mafft.cbrc.jp/ alignment/server/) (Katoh et al. 2017), following the G-INS-I algorithm. Nucleotide substitution models were ascertained using jModeltest v2.1.7 (Darriba et al. 2012) run with the Akaike information criterion, with HKY $+\mathrm{I}+\gamma$ identified for acl and GTR + $\mathrm{I}+\gamma$ identified for all other datasets. Phylogenetic analysis were carried out employing maximum likelihood (ML) using RaxML v8.1.22 (Stamatakis 2014) implemented in the RaxML GUI v1.5b1 (Silvestro and Michalak 2012) and Bayesian (BI) approaches using MrBayes v3.2.5 (Ronquist et al. 2012) using a partitioned approach, and treating gaps as missing data. Using random starting trees, MrBayes analyses were run for 10 million generations with four Metropolis-coupled Markov chain Monte Carlo (MCMC) chains (Huelsenbeck and Rannala 2004), with samples taken every 1,000th generation. The stationarity and convergence of MCMC chains was visualized using TRACER v1.6 (Rambaut et al. 2013), leading to removal of $25 \%$ of the trees. Posterior probabilities were calculated using the "sumt" command and a majority rule consensus tree was constructed. Branch support for ML analyses was assessed with 1,000 nonparametric bootstrapping replicates using the same partitioned model parameters as described above, followed by a search for the best-scoring ML tree. Posterior probabilities $\geq 0.95$ and bootstrap values $\geq 0.70$ were taken as evidence for support of the branches (Huelsenbeck and Rannala 2004). FigTree v1.4.3 was used to visualize the resultant phylogenies, with the root placed with the outgroup taxa Cosmospora coccinea and N. pseudotrichia (Lombard et al. 2015; Rambaut 2014).

Whole genome sequencing and assembly. Fungal isolates $\mathrm{Co}$. pachysandricola JAC 16-16 (CBS 128674), Ps. buxi AR 2714 (CBS 144729), and Ps. foliicola JAC 18-02 (CBS 144753) were grown for 1 week in potato dextrose broth (Difco Laboratories, Sparks, MD) at room temperature with constant shaking. Genomic DNA was extracted from harvested tissue using liquid nitrogen and the OmniPrep for Fungi kit (G-Biosciences, St. Louis, MO). Genomic DNA was cleaned using the Genomic DNA Clean and Concentrator-10 (Zymo Research, Irvine, CA), quantified using a Qubit 2.0 fluorometer (Invitrogen, Carlsbad, CA), and evaluated visually for integrity on a $1 \%$ agarose gel. Genomic DNA libraries were prepared using TruSeq DNA Nano kits (Illumina Inc., San Diego, CA) and quantified using the quantitative PCR-based KAPA Library Quantification Kit (Kapa Biosystems, Wilmington, MA). Libraries were sequenced as paired-end reads using a 600-cycle MiSeq Reagent Kit v3 cartridge on a MiSeq sequencer (Illumina Inc.). After removal of adapters and low-quality reads (nucleotide sites with Phred scores $<0.05$ and $<30 \mathrm{bp}$ in length were discarded), genomes were assembled using CLC Genomics Workbench v7.5.1 (QIAGEN Inc.) using default settings $(\mathrm{kmer}=20$, bubble $=50)$. Assembly quality statistics were measured using QUAST (Gurevich et al. 2013). Genes were predicted using the AUGUSTUS webserver (http://bioinf.unigreifswald.de/webaugustus/) with the Fusarium graminearum species model (Stanke and Morgenstern 2005). Assembly completeness was assessed from the predicted protein sequences using BUSCO v3 with the Fungi and Eukaryota datasets (Waterhouse et al. 2017). Transposable elements (TEs) were identified using the REPET v2.5 pipeline (Flutre et al. 2011) following the protocol detailed in Rivera et al. (2018).

Plant inoculations. Four fungal isolates were used for pathogenicity tests: two isolated from S. hookeriana (Co. pachysandricola JAC16-16 and JAC 16-17), one isolated from $P$. terminalis (Co. pachysandricola JAC 16-19), and one isolated from Buxus sp. (Ps. foliicola N1) (Table 1). Prior to conducting experiments with whole plants, a pilot experiment was performed on detached leaves to determine the optimum spore concentration needed to cause disease lesions and to assess the influence of wounding on symptom development. For detached leaf experiments, leaves were harvested at the base of the petiole from gallon-pot-sized plants of $S$. hookeriana, $P$. terminalis, and B. sempervirens 'Suffruticosa' and surfacesterilized for $60 \mathrm{~s}$ in $10 \%$ bleach $(0.08 \% \mathrm{NaOCl})$. While all leaves were wounded at the detachment point when harvested, two additional wounds were made on either side of the midrib for half of the leaves using a sterile dissecting needle. For each host/ isolate combination, four moist chambers were prepared $(9-\mathrm{cm}$ Petri dishes lined with Whatman filter paper). Eight to 10 leaves of pachysandra and sarcococca (four to five "wounded", four to five "unwounded") and 20 leaves of boxwood (10 "wounded" and 10 "unwounded") were distributed in moist chambers in single layers. Leaves were placed with the adaxial surface down on the filter paper. Spores of each isolate were collected by adding $10 \mathrm{~mL}$ of sterile water to 2-week-old colonies on half-strength PDA plates and swirling and decanting the suspension. Spore suspensions were adjusted to $\sim 150,000$ spores $\mathrm{mL}^{-1}$ and sprayed over the leaves in moist chambers using a DeVilbiss apparatus (DeVilbiss Healthcare, Port Washington, NY) attached to an air source at $138 \mathrm{kPa}$. Two plates of half-strength PDA were also sprayed using the spore solutions to confirm spore viability. Negative controls consisted of the same number of leaves per host as used in the experimental treatments; leaves were sprayed with sterilized distilled water. Moist chambers were stacked in sealable plastic bags ( 8 to 10 moist chambers per bag), placed in a growth chamber at $20^{\circ} \mathrm{C}$ with a $14-\mathrm{h}$ photoperiod and arranged in a randomized complete block design. Leaves were rated after 6 to 10 days, until no further changes were observed. If asexual fruiting structures (sporodochia) were observed in lesions, the leaf surface was scraped with a sterile dissecting needle to remove pink spore masses for microscopic examination at $400 \times$ and plating on half-strength PDA.

For whole-plant pathogenicity experiments, 2- to 3-month-old rooted cuttings from $S$. hookeriana, $P$. terminalis, and B. sempervirens 'Suffruticosa' plants (rooted in $5-\mathrm{cm}$ pots) were inoculated separately using three of the fungal isolates used for the detached leaf experiments (JAC 16-16, JAC 16-17, and N1). For each fungal isolate, eight plants of each species were inoculated with approximately 150,000 spores $\mathrm{mL}^{-1}$ using a DeVilbiss apparatus attached to an air 
source at $138 \mathrm{kPa}$. Eight plants were sprayed with sterile distilled water as negative controls. Four of the plants had six leaves tagged and wounded with a dissecting needle at each side of the midrib; the other four plants had six leaves tagged but not wounded. Plants were incubated overnight in a dew chamber set at $20^{\circ} \mathrm{C}$, then placed in the greenhouse at 22 to $24^{\circ} \mathrm{C}$ and carefully hand-watered to avoid splashes. Two weeks after inoculation, plants were assessed for water-soaked lesions on leaves. Symptomatic leaves were placed in moist chambers and the presence of the pathogen was confirmed by scraping pink spore masses off leaves with a sterile dissecting needle and examining spore morphology under the microscope at $400 \times$, followed by plating of the remaining spores on halfstrength PDA to confirm identity by colony morphology after 7 days.

Availability of data and fungal isolates. Voucher specimens of diseased sarcococca and pachysandra described in this study were deposited at the U.S. National Fungus Collection (BPI 910731 and BPI 910730, respectively). Representative fungal isolates, including those for which a genome sequence was generated, were deposited at CBS (Table 1). Phylogenetic marker sequence data were submitted to the National Center for Biotechnology Information GenBank and assigned accession numbers (Table 1). The whole genome shotgun projects described in this article were deposited at DDBJ/ENA/GenBank under accession numbers QUZF00000000
(Co. pachysandricola JAC16-16), QUZG00000000 (Ps. buxi AR 2414), and QUZD00000000 (Ps. foliicola JAC18-02).

\section{Results}

Disease symptoms. In September 2016, patches of wilting and dying $S$. hookeriana plants were observed at the National Boxwood Collection in the USNA in Washington, DC. Leaves of S. hookeriana showed irregular tan-to-brown spots that enlarged to form blotches, with concentric lighter and darker zones with dark-brown margins (Fig. 1, A to D). These necrotic blotches gradually increased in size until the entire leaf turned brown or black and died, remaining attached to the plant. No asexual or sexual fruiting bodies were observed on diseased leaves or any other portion of the plant. P. terminalis growing adjacent to the $S$. hookeriana plants also exhibited similar foliar symptoms (Fig. 1, E and F). Disease incidence was $100 \%$ for P. terminalis and $50 \%$ for S. hookeriana.

Morphological observations. Fungi obtained from diseased $S$. hookeriana and $P$. terminalis grew as effuse salmon- and whitecolored colonies on PDA, reaching 26 to $35 \mathrm{~mm}$ after 10 days at $25^{\circ} \mathrm{C}$ (Fig. 2, A and B). Microscopic examination of the isolates revealed the presence of pale-salmon sporodochia with verticillate conidiophores, 82 to $107 \mu \mathrm{m}$ in diameter (Fig. 2C), and simple conidiophores as lateral phialides on somatic hyphae (Fig. 2D). No setae were observed on sporodochia formed on PDA. Phialides were
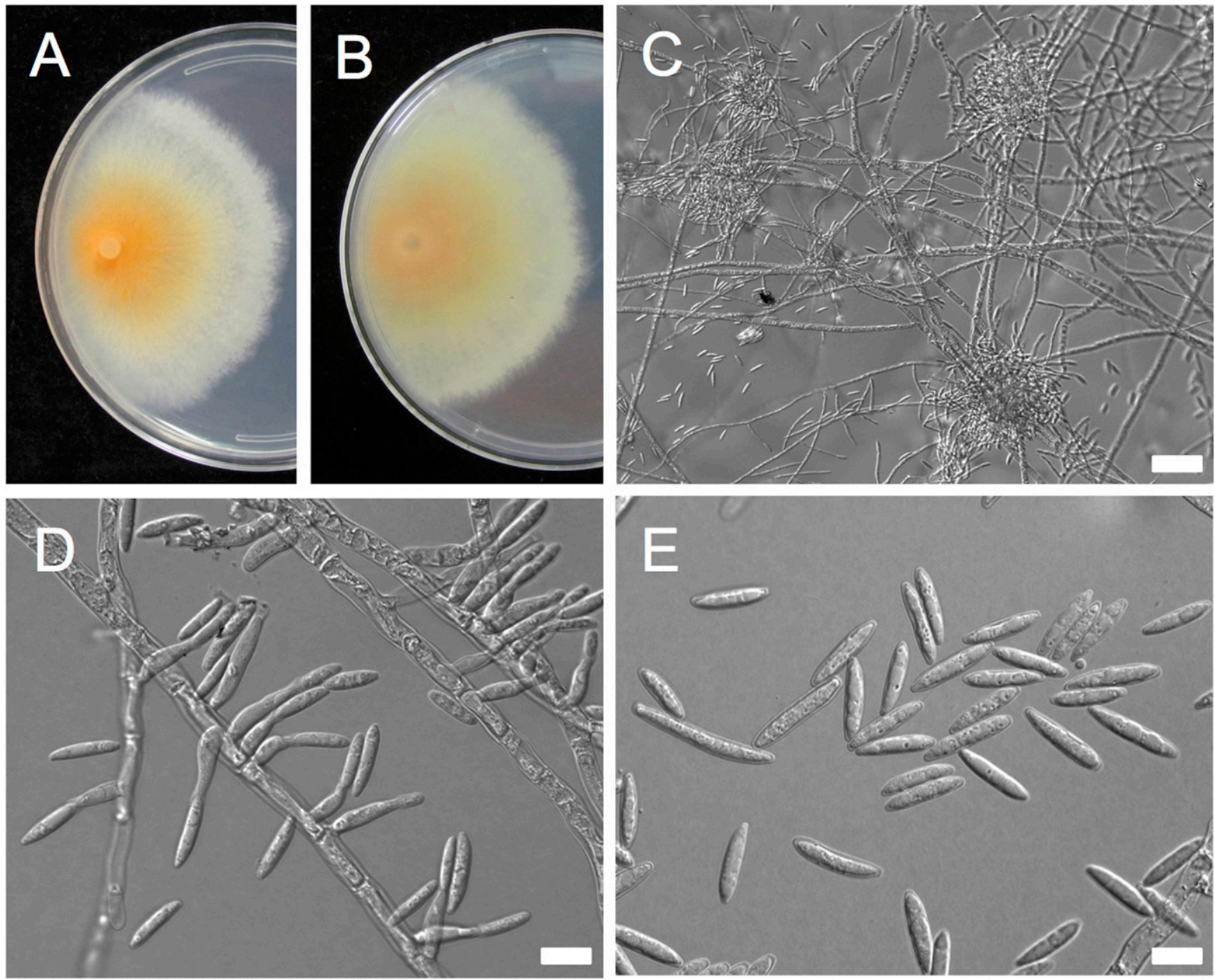

Fig. 2. Morphological features of Coccinonectria pachysandricola isolate JAC 16-16 (= CBS 144731) isolated from diseased Sarcococca hookeriana var. humilis. A and B, Co. pachysandricola isolate colony appearance on potato dextrose agar (A, front; B, reverse). C, Young sporodochia. D, Simple conidiophores as lateral phialides on somatic hyphae. $\mathrm{E}$, Conidia. Scale bars $=50 \mu \mathrm{m}$ in $\mathrm{C}$ and $10 \mu \mathrm{m}$ in $\mathrm{D}$ and $\mathrm{E}$. 
cylindrical ( 8 to $25 \times 2$ to $5 \mu \mathrm{m}$; average $15.2 \times 3.3 \mu \mathrm{m}, n=47$; Fig. $2 \mathrm{D})$, with an inconspicuous collarete. Conidia were aseptate, hyaline, and ellipsoidal to fusiform ( 11 to $23 \times 2$ to $5 \mu \mathrm{m}$; average $15.4 \times$ $3.1 \mu \mathrm{m}, n=54$; Fig. 2E). These observations are consistent with those described for Co. pachysandricola, a fungus known as a foliar pathogen of pachysandra (Dodge 1944; Lombard et al. 2015). Although the cultures of fungi isolated from sarcococca and pachysandra were morphologically similar to related species in the Nectriaceae associated with hosts in the Buxaceae (i.e., Ps. buxi and Ps. foliicola), the isolates of Co. pachysandricola were distinguished by the size of their conidia (Ps. buxi: 8 to $12 \times 2.5$ to $3 \mu \mathrm{m}$, Bezerra 1963; Ps. foliicola: 6.5 to $7.5 \times 2$ to $3 \mu \mathrm{m}$, Lombard et al. 2015). No sexual fruiting structures were observed in cultures.

Phylogenetic analyses. The concatenated sequence alignment generated from 39 Nectriaceae fungi for all six markers was 4,879 bp. ML and BI phylogenetic tree topologies were identical; the BI topology is shown in Figure 3. ML and BI phylogenetic analysis of this data set agreed with the morphology-based identification of the fungal isolates as Co. pachysandricola (Fig. 3). The phylogeny supported the differentiation of Co. pachysandricola and related fungi: namely, Ps. buxi, Ps. foliicola, V. ciliata, and V. consors. The phylogenetic analyses showed that Co. pachysandricola was more closely related to species in the genus Volutella than to species in the genus Pseudonectria.

Pathogenicity tests. Inoculation of detached leaves with Co. pachysandricola showed that isolates originating from sarcococca and pachysandra produced similar levels of lesion development on all tested hosts (Table 2). All three Co. pachysandricola isolates caused similar leaf lesions on both sarcococca and pachysandra, but they failed to produce any lesions on boxwood. In contrast, $P$ s. foliicola isolate $\mathrm{N} 1$, which originated from $B$. sempervirens, caused lesions on all three tested hosts, although it failed to infect unwounded sarcococca. The percentage of boxwood leaves exhibiting lesions attributable to Ps. foliicola was, however, much greater than that exhibited from detached leaves of pachysandra and sarcococca. The majority of leaf infections by Co. pachysandricola and Ps. foliicola occurred at wound sites, whether the wound sites were intentionally inflicted as puncture wounds, wounds as a result of detachment scars, or incidental wounds on the leaf. Lesions occasionally were observed on apparently unwounded tissue. A few control leaves of boxwood developed lesions with spores resembling those of the Ps. foliicola isolate N1, which may have resulted from endophytic colonization of the original plant.

Pathogenicity results using whole plants were similar to the detached leaf assays (Table 3). Co. pachysandricola isolates originally collected from pachysandra and sarcococca caused similar symptoms on both host plants but not on boxwood. The Ps. foliicola isolate originally collected from $B$. sempervirens infected leaves of inoculated boxwood cuttings only. No lesions were observed on control plants (water-inoculated without spores). Wounding was not necessary for infection. The presence of Co. pachysandricola and Ps. foliicola on symptomatic leaves was confirmed by microscopic examination and colony morphology.

Genome sequence resources. To provide resources for the three fungal species that cause Volutella blight diseases, genome sequence assemblies were generated for Co. pachysandricola JAC 16-16, Ps. buxi AR 2714, and Ps. foliicola JAC 18-02 (Table 4). For each isolate, 4.8 to 5.7 million paired-end reads were generated. These data were assembled into genome sequences represented by at least $50 \times$ sequence coverage, with $\mathrm{N} 50$ values (scaffold/contig length at which $50 \%$ of the total assembly length is covered) ranging from 281,033 to 390,316 . The overall size of the genome assemblies differed between the three species. Co. pachysandricola JAC 16-16 had the smallest assembly $(25.7 \mathrm{Mb})$, followed by Ps. buxi AR $2714(27.9 \mathrm{Mb})$ and Ps. foliicola JAC 18-02 (28.5 Mb). The number of predicted gene models also differed between the species but did not directly correspond with genome size, as $P$ s. foliicola had fewer $(8,846)$ predicted genes than Ps. buxi $(9,228)$. Comparison of predicted proteins to fungal and eukaryotic single-copy ortholog data sets indicated that the three assemblies were approximately $98 \%$ complete (Table 4 ). TEs were rare within the three assemblies. Five-hundred and two TEs were identified in Co. pachysandricola JAC 16-16 (1.6\% of the genome), 428 TEs in Ps. buxi AR 2714 (1.2\% of the genome), and 103 TEs in Ps. foliicola JAC 18-02 (0.5\% of the genome). The conserved alpha domain indicative of the MAT1-1 mating type idiomorph was identified in Ps. buxi (contig 5) and Ps. foliicola (contig 31) but was absent in Co. pachysandricola. The HMG-box region indicative of the MAT1-2 mating type was identified in Co. pachysandricola (contig 147) but was absent in Ps. buxi and Ps. foliicola. Based on these data, all three of these fungi possessed mating type loci consistent with the organization found in heterothallic ascomycetes.

\section{Discussion}

The objective of this research was to determine the causal agent of an unknown disease affecting $S$. hookeriana. The combined results of morphological, phylogenetic, and pathogenicity analyses identified Co. pachysandricola as the causal agent of the disease. To our knowledge, Co. pachysandricola has not been previously reported as a pathogen of sarcococca, and our finding expands the known hosts in the Buxaceae that are susceptible to Volutella blight diseases. In addition, this is the first known report of Co. pachysandricola causing Volutella blight of $P$. terminalis in Washington, DC (Farr and Rossman 2018). Volutella blight of pachysandra has been a well-known disease throughout the eastern United States since the early 20th century (e.g., in Connecticut, Delaware, Maryland, Pennsylvania, New Jersey, New York, North Carolina, Virginia, and West Virginia; Farr and Rossman 2018). It therefore seems likely that Volutella blight of pachysandra is probably not new to Washington, DC, and that the disease has merely gone undocumented in this location until now.

As a result of the spread of boxwood blight disease in the United States since late 2011, there is increased interest in determining whether plants such as sarcococca and pachysandra can serve as reservoirs of boxwood pathogens (Kong and Hong 2018; LeBlanc et al. 2018). S. hookeriana was recently reported as a new host of $C$. pseudonaviculata, the causal agent of boxwood blight disease (Kong et al. 2017a; Malapi-Wight et al. 2016). Both occurrences of C. pseudonaviculata on sarcococca happened when the affected plants were grown in the vicinity of $B$. sempervirens infected with $C$. pseudonaviculata and symptomatic for boxwood blight disease (Kong et al. 2017a; Malapi-Wight et al. 2016). A similar scenario of naturally occurring infections of two different Buxaceae hosts by $C$. pseudonaviculata was recently documented from a landscape where colocated $B$. sempervirens and $P$. terminalis exhibited disease symptoms (Kong et al. 2017b). Similarly, in the present study, we observed $S$. hookeriana plants growing adjacent to $P$. terminalis plants with severe Volutella blight symptoms caused by Co. pachysandricola. The original source of the pathogen was not determined in any of these two-host scenarios. It is unknown whether the infection of one plant led to the infection of the other plant, or vice versa, or whether the disease outbreaks on the two hosts were independent from one another. Where molecular data were collected, there were insufficient differences on the molecular level to allow discrimination between the host isolates collected from the colocated hosts. Malapi-Wight et al. (2016) showed that C. pseudonaviculata isolates from $B$. sempervirens and $S$. hookeriana differed from one another by just a single nucleotide across the entire $54 \mathrm{Mb}$ genome. In the current study, phylogenetic analysis of nucleotide sequences from six molecular markers showed that the Co. pachysandricola isolates affecting $S$. hookeriana and $P$. terminalis were identical.

Although the boxwood blight pathogen C. pseudonaviculata is capable of colonizing and inducing disease in three genera of plants in the Buxaceae (Kong and Hong 2018; Kong et al. 2017a, 2017b; LaMondia 2017; LaMondia and Li 2013; LaMondia et al. 2013; LeBlanc et al. 2018; Malapi-Wight et al. 2016), our experimental data showed that Co. pachysandricola and Ps. foliicola may be more limited in their host ranges. Co. pachysandricola has never been reported as a pathogen of boxwood and according to the results obtained in the current study, this fungus did not cause disease symptoms following artificial inoculation of whole plants or detached 
boxwood leaves, even when leaves were wounded. This finding agrees with the results of Hutchinson (1929), who also reported the absence of disease symptoms on boxwood inoculated with $C o$. pachysandricola. Conversely, Ps. buxi and Ps. foliicola are only known as pathogens of boxwood, which agrees with our findings that inoculations of pachysandra and sarcococca with $P$ s. foliicola did not lead to disease in these hosts. However, we cannot rule out the possibility that each of these species might be capable of interacting with other plants without causing disease, either as endophytes or as saprophytes. Furthermore, the failure to infect the single species of each of the plants tested does not guarantee that other species in the same genera might not be hosts. Coccinonectria and Pseudonectria are genera in the Nectriaceae, a family containing a diverse cohort of pathogens, saprophytes, and endophytes, but the potential role of these fungi as nonpathogenic organisms is understudied (Lombard et al. 2015). Endophytes are poorly understood in general, and the

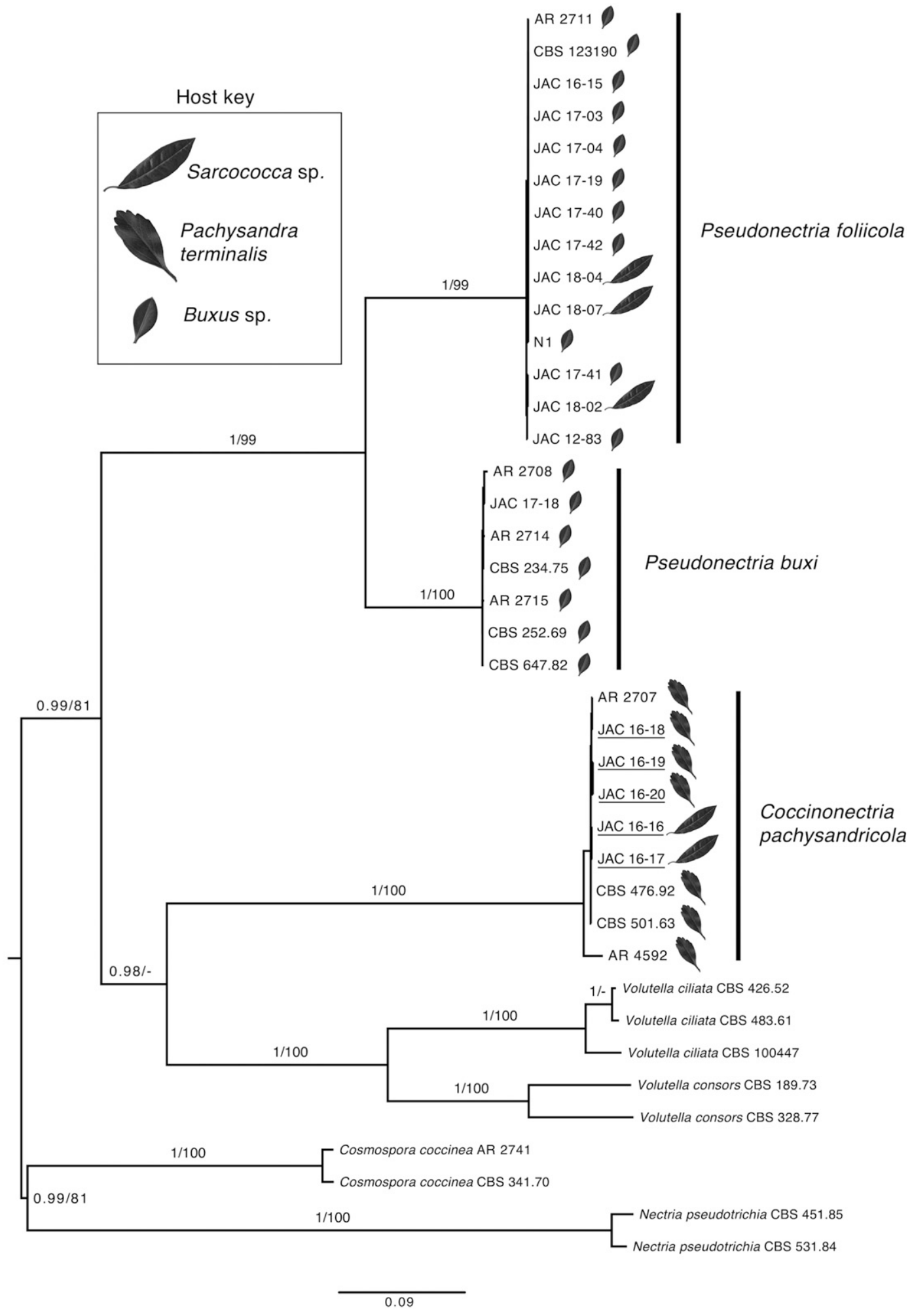

Fig. 3. Majority rule Bayesian phylogenetic tree from the combined analysis of six loci showing relationships among fungal isolates associated with diseases of Buxaceae hosts. Underlined are the Coccinonectria pachysandricola strains isolated in this study clustering together with verified exemplar isolates of the species. Cosmospora coccinea and Nectria pseudotrichia were used as outgroups. Support values (posterior probability [PP]/maximum likelihood [ML] bootstrap) are indicated above the branches. The absence of a number above the branch indicates that the clade/branch was not supported at values $\geq 0.95 \mathrm{PP} / 70 \% \mathrm{ML}$ bootstrap. 
boundary between an endophyte and an opportunistic pathogen is diffuse (Schulz and Boyle 2005). Both Ps. buxi and Ps. foliicola have been reported as endophytes (Bills and Polishook 1994; Collado et al. 1999). Similarly, one of the isolates used in our phylogenetic analysis, Ps. foliicola JAC 18-02, originated from sarcococca, demonstrating that this fungus is able to naturally infect plants other than boxwood. Hutchinson (1929) also provided evidence that Co. pachysandricola and Ps. buxi can survive as saprophytes in dead leaves of boxwood, suggesting a role for leaf litter in the life cycle of both pathogens.

Co. pachysandricola is primarily regarded as an opportunistic parasite or wound pathogen of pachysandra, colonizing plant tissues that are stressed as a result of winter or heat damage, insect infestation, mechanical injury, transplant shock, drought, or desiccation (Hudler and Banik 1986; Sinclair et al. 1987). Early infectivity studies established Co. pachysandricola as a wound pathogen (Dodge 1944; Hutchinson 1929; Pirone 1942). Later studies of wound repair mechanisms demonstrated that wounded $P$. terminalis stems provided a suitable site for infection by $C o$. pachysandricola, provided that the wounds were less than 2 to 4 days old, before the host produces primary ligno-suberized tissue at the wound site (Hudler and Banik 1986; Hudler et al. 1990). However, these investigations were based on comparisons between wounds of different ages and did not include unwounded tissue. The results of the current study conflict with the earliest reports of this pathogen as a wound pathogen, as our experiments demonstrate that wounding is not required for $C o$. pachysandricola to cause disease symptoms in sarcococca or pachysandra. This was also observed in the experiments with Ps. foliicola, another fungus regarded as a weak pathogen of boxwood and widely assumed to be dependent on wounds (Rivera et al. 2018) but shown here to cause disease on unwounded boxwood leaves. It is possible that the infection of unwounded sarcococca or pachysandra could be correlated with differences in inoculum pressure and

Table 2. Number of lesions on detached leaves of boxwood, pachysandra and sarcococca after artificial inoculation with Coccinonectria pachysandricola (isolates JAC 16-16 and JAC 16-17 originating from Sarcoccocca hookeriana, isolate JAC 16-19 originating from Pachysandra terminalis) or Pseudonectria foliicola (isolate N1 originating from Buxus sempervirens)

\begin{tabular}{|c|c|c|c|c|c|c|c|}
\hline \multirow[b]{3}{*}{ Species } & \multirow[b]{3}{*}{ Isolate } & \multicolumn{6}{|c|}{ Inoculated host leaf } \\
\hline & & \multicolumn{2}{|c|}{ S. hookeriana } & \multicolumn{2}{|c|}{ P. terminalis } & \multicolumn{2}{|c|}{ B. sempervirens } \\
\hline & & Wounded & Unwounded & Wounded & Unwounded & Wounded & Unwounded \\
\hline Co. pachysandricola & JAC 16-16 & $68^{\mathrm{a}}$ & 55 & 55 & 25 & 0 & 0 \\
\hline Co. pachysandricola & JAC $16-17$ & 74 & 45 & 68 & 40 & 0 & 0 \\
\hline Co. pachysandricola & JAC 16-19 & 68 & 45 & 58 & 35 & 0 & 0 \\
\hline \multirow[t]{2}{*}{ Ps. foliicola } & N1 & 25 & 0 & 10 & 10 & 95 & 48 \\
\hline & Control (water) & 0 & 0 & 0 & 0 & 3 & 3 \\
\hline
\end{tabular}

a Values are expressed as average percent infection of leaves obtained from two trials.

Table 3. Pathogenicity of Coccinonectria pachysandricola (isolate JAC 16-16 originating from Sarcoccocca hookeriana; isolate JAC 16-17 originating from Pachysandra terminalis) or Pseudonectria foliicola (isolate N1 originating from Buxus sempervirens) on rooted cuttings of boxwood, pachysandra, and $\operatorname{sarcococca}^{\mathrm{a}}$

\begin{tabular}{|c|c|c|c|c|c|c|c|}
\hline \multirow[b]{3}{*}{ Species } & \multirow[b]{3}{*}{ Isolate } & \multicolumn{6}{|c|}{ Inoculated host plant } \\
\hline & & \multicolumn{2}{|c|}{ S. hookeriana } & \multicolumn{2}{|c|}{ P. terminalis } & \multicolumn{2}{|c|}{ B. sempervirens } \\
\hline & & Wounded & Unwounded & Wounded & Unwounded & Wounded & Unwounded \\
\hline Co. pachysandricola & JAC $16-17$ & $25 / 12$ & $12 / 2$ & $24 / 4$ & $36 / 13$ & $0 / 0$ & $0 / 0$ \\
\hline Co. pachysandricola & JAC $16-16$ & $75 / 16$ & $38 / 6$ & $38 / 8$ & $0 / 0$ & $0 / 0$ & $0 / 0$ \\
\hline \multirow[t]{2}{*}{ Ps. foliicola } & N1 & $0 / 0$ & $0 / 0$ & $0 / 0$ & $0 / 0$ & $75 / 17$ & $50 / 17$ \\
\hline & Control (water) & $0 / 0$ & $0 / 0$ & $0 / 0$ & $0 / 0$ & $0 / 0$ & $0 / 0$ \\
\hline
\end{tabular}

${ }^{a}$ Resulting values from two experiments are expressed as average percent infection of plants per experiment/number of infected leaves per experiment.

Table 4. Genome assembly and annotation statistics for sequenced isolates of Coccinonectria pachysandricola JAC 16-16, Pseudonectria buxi AR2714, and Ps. foliicola JAC $18-02^{\mathrm{a}}$

\begin{tabular}{lccc}
\hline Isolate information & $\begin{array}{c}\text { Co. pachysandricola JAC 16-16 } \\
\text { (CBS 128674) }\end{array}$ & $\begin{array}{c}\text { Ps. buxi AR 2714 } \\
\text { (CBS 144729) }\end{array}$ & $\begin{array}{c}\text { Ps. foliicola JAC 18-02 } \\
\text { (CBS 144753) }\end{array}$ \\
\hline Host & $\begin{array}{c}\text { Sarcoccocca hookeriana } \\
\text { District of Columbia, U.S.A., 2016 }\end{array}$ & $\begin{array}{c}\text { Buxus sempervirens } \\
\text { Spain, } 1998\end{array}$ & $\begin{array}{c}\text { S. hookeriana } \\
\text { North Carolina, U.S.A., 2018 }\end{array}$ \\
Geographic origin and year of collection & 25.7 & 27.9 & 28.5 \\
Total assembly length (Mbp) & 4.8 & 5.6 & 5.7 \\
Reads (million) & $52 \times$ & $54 \times$ & $56 \times$ \\
Mean sequence coverage & 390,316 & 296,186 & 281,033 \\
N50 & 359 & 342 & 233 \\
Number of contigs & $1,289,737$ & 783,162 & 861,355 \\
Largest contig (bp) & 7,898 & 9,228 & 8,846 \\
Predicted gene models & 98.6 & 97.6 & 98.9 \\
BUSCO fungi $(\%)^{\mathrm{c}}$ & 98 & 98.7 & 98.4 \\
BUSCO eukaryote $(\%)^{\mathrm{c}}$ & 1.6 & 1.2 & 0.5 \\
Transposable elements $(\%)^{\mathrm{d}}$ & 502 & 428 & 103 \\
Complete transposable elements (count) & & & \\
\hline
\end{tabular}

${ }^{\mathrm{a}}$ Minimum scaffold length for all assemblies $=500 \mathrm{bp}$.

${ }^{\mathrm{b}} \mathrm{N} 50=$ scaffold/contig length at which $50 \%$ of the total assembly length is covered.

${ }^{c}$ Percentage of complete BUSCOs found, based on 429 total eukaryote and 1,438 fungal BUSCO groups searched.

${ }^{\mathrm{d}}$ Percentage of the total nuclear genome assembly containing transposable elements. 
environmental factors such as temperature and humidity, all of which are thought to be important factors in the development of this disease (Douglas 2008; Hudler and Banik 1986; Hudler et al. 1990). For example, our experiments were conducted at $20^{\circ} \mathrm{C}$, whereas Hutchinson (1929) worked with the pathogen at $28^{\circ} \mathrm{C}$, which he determined as optimal for spore germination and mycelial growth. There is evidence that temperature influences the susceptibility of pachysandra to the pathogen, with lower temperatures being more conducive to infection (Hudler and Banik 1986). In field trials, Hudler and Banik (1986) showed that the time of year that P. terminalis was inoculated with Co. pachysandricola influenced infection success. Wounded tissue quickly ( $<2$ days) becomes immune to infection during the hottest months of the year (summer to early fall), whereas wounded tissue remained susceptible to Co. pachysandricola for up to 4 days during cooler months (spring). Overall, very few rigorous investigations of how Co. pachysandricola is influenced by the environment to cause disease have been conducted and research is needed to fully understand the nature of these key pathogens of the Buxaceae.

In this study, we generated whole genome resources for the three fungal species associated with Volutella blights affecting hosts in the Buxaceae to aid in the development of improved tools for diagnostics, taxonomy, and epidemiological studies and to facilitate comparative genomic investigations of these destructive plant pathogens. These resources are the first available for Co. pachysandricola and Ps. buxi, and they are the first genome resources for Ps. foliicola collected from an S. hookeriana host. Compared with other fungi in the Nectriaceae, the genome sizes of these fungi were quite small, ranging from $25.7 \mathrm{Mb}$ to $28.4 \mathrm{Mb}$. The genome assembly for Co. pachysandricola represents the smallest nuclear genome reported to date for the Nectriaceae, whose sizes range between 28 and $58 \mathrm{Mb}$ (Malapi-Wight et al. 2015; Mohanta and Bae 2015; Rivera et al. 2018; Salgado-Salazar and Crouch 2018). Small fungal genomes and an associated reduction in the number of genes have been associated with host range contractions (Baroncelli et al. 2016), lifestyle specialization (de Man et al. 2016), and the presence or absence of TEs (Castanera et al. 2016). The limited host range of Co. pachysandricola, Ps. buxi, and Ps. foliicola may account for their relatively small genome sizes compared with other pathogens with a broader host range. The limited number of TEs observed (comprising 0.5 to $1.6 \%$ of the total genome) is another factor that likely contributed to the small size of the genome, as a moderate correlation between total TE abundance and genome size in fungi has been described (Elliott and Gregory 2015).

Although the initial reports of Co. pachysandricola by Dodge (1944) described the presence of sexual fruiting bodies (perithecia) on infected plant stems, we did not observe perithecia from the stems or leaves of the infected pachysandra or sarcococca. Perithecia were also absent from pure cultures of the fungus. The lack of perithecia might have been due to the time of our sample collection, as Dodge (1944) described Co. pachysandricola fruiting body production as occurring during the spring and summer, whereas our samples were collected in September, at the beginning of autumn. Alternatively, based on the fact that only a single mating type idiomorph (MAT1-2) was identified from the Co. pachysandricola genome, it is possible that the absence of sexual structures was a result of the absence of the alternative mating type. The production of perithecia in natural populations described by Dodge suggests that he was working with either a homothallic fungus or with a mixed population of heterothallic individuals. Several of Dodge's Co. pachysandricola specimens are preserved within the U.S. National Fungus Collections, which could facilitate further investigations.

Diseases of Buxaceae collectively referred to as Volutella blights are associated with three species of fungi in the Nectriaceceae: $C o$. pachysandricola, Ps. buxi, and Ps. foliicola (Lombard et al. 2015). The common name used to describe these diseases is an artifact of obsolete taxonomy, ascribed prior to the adoption of single-name nomenclature for fungi. Affiliation of these pathogens with the genus Volutella dates back to the time when the asexual morphs were considered species of Volutella, distinct from the sexual morphs, which were classified separately as species of Pseudonectria (Dodge 1944; Rossman et al. 1999). Molecular phylogenetic studies restricted Volutella to only those species that are members of the clade that includes $V$. ciliata, $V$. consors, $V$. citronella, $V$. minima, and $V$. rosea (Gräfenhan et al. 2011; Lombard et al. 2015). The outcome of this revised taxonomy was the exclusion of pathogens of Buxaceae from the genus Volutella. Ps. buxi has been assigned to at least 10 different genera since it was first described in 1815 , including the name originally used to describe the asexual morph, $V$. buxi (Rossman et al. 1999). However, molecular phylogenetic evidence showed that $P s$. buxi, along with the recently identified Ps. foliicola, groups separately from the Volutella sensu stricto clade (Gräfenhan et al. 2011; Lombard et al. 2015; this study). Co. pachysandricola was originally described in 1944 as Pseudonectria pachysandricola with the conidial stage of the life cycle named V. pachysandricola (Dodge 1944). Although the fungus is closely related to Volutella, it is a part of a distinct phylogenetic lineage, which led to the establishment of the new genus Coccinonectria to accommodate this pathogen and the related species Co. rusci (Lombard et al. 2015). Given the fact that none of the so-called Volutella blight fungi are actually members of the genus Volutella, we suggest that the common names of these and other blight diseases of Buxaceae be reconsidered in light of the modern taxonomy. For example, adoption of common names such as Coccinonectria blight and Pseudonectria blight for these diseases would more accurately communicate information about the pathogens and could be applied equally well to any affected host plant in the Buxaceae.

In September 2018, a follow-up visit to the original location at the USNA where the diseased $S$. hookeriana and $P$. terminalis were collected in 2016 revealed that the sarcococca plants were still alive, although disease symptoms were still present and the plants were in very poor health. The USNA removed the diseased stand of pachysandra described in this study during the summer of 2017 because of widespread defoliation and plant death (S. Luria, personal communication). Interestingly, a small stand of healthy pachysandra remains in the planting bed but is confined to a shaded area, outside of the sun-exposed area where the diseased plants were found earlier (C. Salgado-Salazar and J. Crouch, personal communication). This observation is consistent with the experiments of Hudler et al. (1990), which demonstrated that pachysandra grown in full sun are more susceptible to disease caused by Co. pachysandricola than those grown in shade.

The impact and extent of Co. pachysandricola infecting sarcococca in the landscape and nursery trade is currently unknown. In this study, Coccinonectria blight is described in detail from a group of plants at a single location within the National Boxwood Collection of the USNA. However, the incidence of this disease on sarcococca was not an isolated case. In September 2018, as this manuscript was in preparation, we observed three additional stands of $S$. hookeriana planted at different locations in the USNA's Asian Collections (beds AC-J-04, AC-C-02 [including accessioned plant NA 28100-H], and adjacent to the parking lot) exhibiting disease symptoms similar to those described in this study (Supplementary Fig. S1), and we confirmed the presence of Co. pachysandricola by establishing the fungus in pure culture (data not shown). Future research is needed to learn more about the economic and ecological impact of this disease affecting hosts in the Buxaceae, including pathogen biology, life cycle, and the factors influencing disease, effective management strategies, pathogen diversity, and host preference.

\section{Acknowledgments}

Mention of trade names or commercial products in this publication is solely for the purpose of providing specific information and does not imply recommendation or endorsement by the U.S. Department of Agriculture (USDA). The USDA is an equal opportunity provider and employer.

\section{Literature Cited}

Baroncelli, R., Amby, D. B., Zapparata, A., Sarrocco, S., Vannacci, G., Le Floch, G., Harrison, R. J., Holub, E., Sukno, S. A., Sreenivasaprasad, S., and Thon, M. R. 2016. Gene family expansions and contractions are associated with host range in plant pathogens of the genus Colletotrichum. BMC Genomics 17:555. 
Batdorf, L. R. 2005. Boxwood Handbook. A Practical Guide to Knowing and Growing Boxwood, 3rd ed. American Boxwood Society, Boyce, VA.

Bezerra, J. L. 1963. Studies on Pseudonectria rousseliana. Acta Bot. Neerl. 12: 58-63.

Bills, G. F., and Polishook, J. D. 1994. Abundance and diversity of microfungi in leaf litter of a lowland rain forest in Costa Rica. Mycologia 86:187-198.

Carbone, I., and Kohn, L. M. 1999. A method for designing primer sets for speciation studies in filamentous ascomycetes. Mycologia 91:553-556.

Castanera, R., López-Varas, L., Borgognone, A., LaButti, K., Lapidus, A., Schmutz, J., Grimwood, J., Pérez, G., Pisabarro, A. G., Grigoriev, I. V., Stajich, J. E., and Ramírez, L. 2016. Transposable elements versus the fungal genome: Impact on whole-genome architecture and transcriptional profiles. PLoS Genet. 12:e1006108.

Castlebury, L. A., Rossman, A. Y., Sung, G.-H., Hyten, A. S., and Spatafora, J. W. 2004. Multigene phylogeny reveals new lineage for Stachybotrys chartarum, the indoor air fungus. Mycol. Res. 108:864-872.

Collado, J., Platas, G., González, I., and Peláez, F. 1999. Geographical and seasonal influences on the distribution of fungal endophytes in Quercus ilex. New Phytol. 144:525-532.

Crous, P. W., Groenewald, J. Z., Risède, J. M., and Hywel-Jones, N. L. 2004. Calonectria species and their Cylindrocladium anamorphs: Species with sphaeropedunculate vesicles. Stud. Mycol. 50:415-430.

Darriba, D., Taboada, G. L., Doallo, R., and Posada, D. 2012. jModelTest 2: more models, new heuristics and parallel computing. Nat. Methods 9:772.

de Man, T. J., Stajich, J. E., Kubicek, C. P., Teiling, C., Chenthamara, K., Atanasova, L., Druzhinina, I. S., Levenkova, N., Birnbaum, S. S., Barribeau, S. M., Bozick, B. A., Suen, G., Currie, C. R., and Gerardo, N. M. 2016. Small genome of the fungus Escovopsis weberi, a specialized disease agent of ant agriculture. Proc. Natl. Acad. Sci. USA 113:3567-3572.

Denaeghel, H., Van Laere, K., Leus, L., Van Huylenbroeck, J., and Van Labeke, M.-C. 2017. Interspecific hybridization in Sarcococca supported by analysis of ploidy level, genome size and genetic relationships. Euphytica 213:149.

Dodge, B. O. 1944. A new Pseudonectria on Pachysandra. Mycologia 36: 532-537.

Douglas, S. M. 2008. Volutella blight of pachysandra. The Connecticut Agricultural Experimental Station. https:/www.ct.gov/caes/lib/caes/ documents/publications/fact_sheets/plant_pathology_and_ecology/volutella_ blight of pachysandra_04-10-08r.pdf

Elliott, T. A., and Gregory, T. R. 2015. Do larger genomes contain more diverse transposable elements? BMC Evol. Biol. 15:69.

Farr, D. F., and Rossman, A. Y. 2018. Fungal Databases, Systematic Mycology and Microbiology Laboratory. U.S. Department of Agriculture, Agricultural Research Service. http://nt.ars-grin.gov/fungaldatabases/

Flutre, T., Duprat, E., Feuillet, C., and Quesneville, H. 2011. Considering transposable element diversification in de novo annotation approaches. PLoS One 6:e16526.

Gräfenhan, T., Schroers, H.-J., Nirenberg, H. I., and Seifert, K. A. 2011. An overview of the taxonomy, phylogeny, and typification of nectriaceous fungi in Cosmospora, Acremonium, Fusarium, Stilbella, and Volutella. Stud. Mycol. 68:79-113.

Gurevich, A., Saveliev, V., Vyahhi, N., and Tesler, G. 2013. QUAST: Quality assessment tool for genome assemblies. Bioinformatics 29:1072-1075.

Hirooka, Y., Rossman, A. Y., Samuels, G. J., Lechat, C., and Chaverri, P. 2012. A monograph of Allantonectria, Nectria, and Pleonectria (Nectriaceae, Hypocreales, Ascomycota) and their pycnidial, sporodochial, and synnematous anamorphs. Stud. Mycol. 71:1-210.

Hudler, G. W., and Banik, M. T. 1986. Wound repair and disease resistance in stems of Pachysandra terminalis. Can. J. Bot. 64:2406-2410.

Hudler, G. W., Neal, B. G., and Banik, M. T. 1990. Effects of growing conditions on wound repair and disease resistance in Pachysandra terminalis. Phytopathology 80:272-277.

Huelsenbeck, J., and Rannala, B. 2004. Frequentist properties of Bayesian posterior probabilities of phylogenetic trees under simple and complex substitution models. Syst. Biol. 53:904-913.

Hutchinson, W. G. 1929. An undescribed species of Macrophoma and of Volutella occurring on Pachysandra terminalis. Mycologia 21:131-142.

Katoh, K., Rozewicki, J., and Yamada, K. D. 2017. MAFFT online service: Multiple sequence alignment, interactive sequence choice and visualization. Brief. Bioinform. bbx 108 .

Kong, P., and Hong, C. 2018. Host responses and impact on the boxwood blight pathogen, Calonectria pseudonaviculata. Planta. Epub ahead of print 2018 Nov 13. doi:10.1007/s00425-018-3041-4

Kong, P., Likinis, T. M., and Hong, C. X. 2017a. First report of blight of Sarcococca hookeriana var. humilis by Calonectria pseudonaviculata in Virginia. Plant Dis. 101:247.

Kong, P., Likinis, T. M., and Hong, C. X. 2017b. First report of Pachysandra terminalis leaf spot by Calonectria pseudonaviculata in Virginia. Plant Dis. 101:509.
LaMondia, J. A. 2017. Pachysandra species and cultivar susceptibility to the boxwood blight pathogen, Calonectria pseudonaviculata. Plant Health Prog. $18: 41-43$.

LaMondia, J. A., and Li, D. W. 2013. Calonectria pseudonaviculata can cause leaf spot and stem blight of Pachysandra procumbens. Plant Health Prog. 14:58.

LaMondia, J. A., Li, D. W., Marra, R. E., and Douglas, S. M. 2013. First report of Cylindrocladium pseudonaviculatum causing leaf spot of Pachysandra terminalis. Plant Dis. 96:1069.

LeBlanc, N., Salgado-Salazar, C., and Crouch, J. A. 2018. Boxwood blight: An ongoing threat to ornamental and native boxwood. Appl. Microbiol. Biotechnol. 102:4371-4380.

Lombard, L., van der Merwe, N. A., Groenewald, J. Z., and Crous, P. W. 2015 Generic concepts in Nectriaceae. Stud. Mycol. 80:189-245.

Malapi-Wight, M., Salgado-Salazar, C., Demers, J. E., Clement, D. E., Rane, K. K., and Crouch, J. A. 2016. Sarcococca blight: Use of whole genome sequencing as a strategy for fungal disease diagnosis. Plant Dis. 100 1093-1100.

Malapi-Wight, M., Salgado-Salazar, C., Demers, J., Veltri, D., and Crouch, J. A 2015. Draft genome sequence of Dactylonectria macrodidyma, a plantpathogenic fungus in the Nectriaceae. Genome Announc. 3: e00278-15.

Mohanta, T. K., and Bae, H. 2015. The diversity of fungal genome. Biol. Proced. Online 17:8.

Nirenberg, H. 1976. Untersuchungen uber die morphologische und biologische Differenzierung in der Fusarium-Sektion Liseola. MittBiol Bundesanst LandForstw Berlin-Dahlem 169:1-117.

Nowrousian, M., Kück, U., Loser, K., and Weltring, K. M. 2000. The fungal acl1 and acl 2 genes encode two polypeptides with homology to the $\mathrm{N}$ - and $\mathrm{C}$ terminal parts of the animal ATP citrate lyase polypeptide. Curr. Genet. 37: 189-193.

O’Donnell, K., Sarver, B. A., Brandt, M., Chang, D. C., Noble-Wang, J., Park, B. J., Sutton, D. A., Benjamin, L., Lindsley, M., Padhye, A., Geiser, D. M., and Ward, T. J. 2007. Phylogenetic diversity and microsphere array-based genotyping of human pathogenic Fusaria, including isolates from the multistate contact lens-associated U.S. keratitis outbreaks of 2005 and 2006. J. Clin Microbiol. 45:2235-2248.

Pirone, P. P. 1942. Stem and stolon canker of pachysandra. Nursery and disease notes. N. J. Agr. Exp. Sta. 14:40-43.

Rambaut, A. 2014. FigTree v1.4.3. http://tree.bio.ed.ac.uk/software/figtree/

Rambaut, A., Suchard, M., and Drummond, A. 2013. Tracer v1.6. http://tree.bio. ed.ac.uk/software/tracer/

Rayner, R. W. 1970. A mycological colour chart. Commonwealth Mycological Institute, Kew, Surrey, U.K.

Rivera, Y., Salgado-Salazar, C., Veltri, D., Malapi-Wight, M., and Crouch, J. A 2018. Genome analysis of the ubiquitous boxwood pathogen Pseudonectria foliicola. PeerJ 6:e5401.

Ronquist, F., Teslenko, M., van der Mark, P., Ayres, D. L., Darling, A., Höhna, S. Larget, B., Liu, L., Suchard, M. A., and Huelsenbeck, J. P. 2012. MrBayes 3.2: Efficient Bayesian phylogenetic inference and model choice across a large model space. Syst. Biol. 61:539-542.

Rossman, A. Y., Samuels, G. J., Rogerson, C. T., and Lowen, R. 1999. Genera of Bionectriaceae, Hypocreaceae and Nectriaceae (Hypocreales, Ascomycetes) Stud. Mycol. 42:1-248.

Salgado-Salazar, C., and Crouch, J. A. 2018. Genome resources for the stem and bark canker pathogens Corinectria fuckeliana, Neonectria hederae and $N$. punicea. Plant Dis. Epub ahead of print 9 Jan 2019 . doi:10.1094/PDIS-0518-0904-A

Schulz, B., and Boyle, C. 2005. The endophytic continuum. Mycol. Res. 109: 661-686.

Sealy, J. R. 1986. A revision of the genus Sarcococca (Buxaceae). Bot. J. Linn. Soc. 92:117-159.

Silvestro, D., and Michalak, I. 2012. raxmlGUI: A graphical front-end for RAxML. Org. Divers. Evol. 12:335-337.

Sinclair, W. A., Lyon, H. H., and Johnson, W. T. 1987. Diseases of Trees and Shrubs. Cornell University Press, Ithaca, NY.

Stamatakis, A. 2014. RAxML version 8: A tool for phylogenetic analysis and postanalysis of large phylogenies. Bioinformatics 30:1312-1313.

Stanke, M., and Morgenstern, B. 2005. AUGUSTUS: A web server for gene prediction in eukaryotes that allows user defined constraints. Nucleic Acids Res. 33:W465-W467.

Waterhouse, R. M., Seppey, M., Simão, F. A., Manni, M., Ioannidis, P., Klioutchnikov, G., Kriventseva, E. V., and Zdobnov, E. M. 2017. BUSCO applications from quality assessments to gene prediction and phylogenomics. Mol. Biol. Evol. 35:543-548.

White, T. J., Bruns, T., Lee, S., and Taylor, J. L. 1990. Amplification and direct sequencing of fungal ribosomal RNA genes for phylogenetics. Pages 315-322 in: PCR Protocols: A Guide to Methods and Applications. M. A Innis, D. H. Gelfnad, J. J. Sninsky, and T. J. White, eds. Academic Press, San Diego, CA. 